\title{
Self-Efficacy, Job Satisfaction, and Organizational Citizenship Behavior (OCB) For Teachers In All State Primary Schools Of Sukoharjo: A Quantitative Analysis
}

\author{
Imam Makruf, IAIN Surakarta, Indonesia, imam.makruf@iain-surakarta.ac.id ORCID: 0000-0001-5040- \\ $372 X$ \\ *Heldy Ramadhan Putra P, IAIN Surakarta, Indonesia, heldyramadhan09@gmail.com ORCID: 0000-0001- \\ 6518-3512 \\ Fauzi Muharom, IAIN Surakarta, Indonesia, fauzi.muharom@iain-surakarta.ac.id ORCID: 0000-0002-1908- \\ 4529 \\ Hafidah, IAIN Surakarta, Indonesia, hafidah.abdullah@iain-surakarta.ac.id ORCID: 0000-0002-0771-5178 \\ Maslamah, IAIN Surakarta, Indonesia, maslamah@iain-surakarta.ac.id ORCID: 0000-0002-2818-5612 \\ *Corresponding author
}

\begin{abstract}
The purpose of this study is to determine the effect of self efficacy and job satisfaction of the organization citizenship behavior (OCB) of primary school teachers in Sukoharjo Regency. This research uses quantitative approach with survey methods. Analysis and interpretation of the data indicate that; (1) self efficacy has a positive direct effect on the OCB, (2) job satisfaction has a positive direct effect on the OCB), and (3)self efficacy has a positive direct effect on job satisfaction.
\end{abstract}

Keywords: self efficacy, job satisfaction, and organizaztional citizenship behavior

Received: 16.11.2020 Accepted: 20.12.2020 $\quad$ Published: 15.01.2021

\section{INTRODUCTION}

The role of teachers in a school is highly needed to increase the productivity of the organization. Beside the principal, teachers are also a part of the success in achieveing the school's vision and mission. Therefore, teachers need to be able to improve their capacity. Teachers' professionalism is a must, and competence is the key to it. In the industrial revolution 4.0 era, teachers are expected to give their best performance, and even exceed their main responsibilities and functions as teachers in order to give maximum services to their students. By doing so, it is expected that the students grow to be ready-tocompete individuals who have the capacity for competition in their next level of lives, such as in universities or even at work.

As an educator, a teacher transfers cognitive, affective, and psychomotor aspcets. Morever, a teacher is expected to perform beyond his main responsibilities and functions as a teacher. In this case, a teacher is expected to perform Organizational Citizenship Behavior (OCB), and to give positive contribution to the school by performing actions that are beyond his job description. OCB can be interpreted as willingness to help others accomplish their duties or solve problems they encounter; also willingness to work overtime; good time management; and willingness to be honest. Some indicators in OCB are the attitude of being open to changes, self developing effort, avoiding conflict with co-workers, not complaining, and always being positive in handling problems.

A good school can be measured from the OCB its components posses. This OCB involves several behaviors; such as helping others, being volunteers for extra tasks, and helping the organization achieve its goals of efficiency and effectiveness. This is in accordance with a statement from (Newstorm dan Davis, 2002) that organizational citizenship behavior as an employee who are organizational citizens engage in positive social acts designed to help others, such as volunteering their efforts on special projects, sharing their time and resources, and proactively coopertaing with others. They also are expected to use their talents and energies fully to help the organization achieve its goals of efficiency and effectiveness.

In reality, to establish strong OCB, several supporting factors are needed in a school. This is because OCB cannot be increased without any interaction with other factors. According to several different literatures, there have been many factors believed to have influence to OCB. Some of the factors are leader member exchange (LMX), trust, work satisfaction, emotional intelligence, self efficacy, organizational culture, management effectivity, organizational committment, and leadership.

Based on the study the researcher conducted in public primary schools in Sukoharjo Regency, by interviewing the coordinator of School Supervisors in Sukoharjo Regency, it was revealed that teachers' 
negative behaviors still existed. Behaviors like late coming to the class, ineffective teaching time management that resulted in finishing the class earlier, undone teaching plan, and no peer discussion regarding creativity and innovation in teaching were still found. Those behaviors showed that the OCB of the public primary school teachers in Sukoharjo Regency is still low.

\section{THEORITICAL FOUNDATIONS}

\section{The effect of self efficacy on OCB}

Self efficacy is often called positive behavior, as stated by (Quick dan Nelson, 2009), "individuals who focus on the positive aspect of themselves, other people, and the work in general are said to have positive affect". Individuals who focus on the positive aspect of themselves, other people and the work in general are said to have positive bahavior. Furthermore, (Quick dan Nelson, 2009)said that "Individuals with positif affect are more satisfied with their jobs. In addition, those with postif affect are more likely to help others at work and also engage in more Organizational Citizenship Behaviors (OCBs)".

\section{The effect of job satisfaction on OCB}

Job satisfaction is a teacher's positive attitude towards his job, which is resulted from the assessment on the work situation. This assessment can be done on one of the work a teacher has done, and is used to show appreciation towards important achievement one made in his jobs. A satisfied teacher tends to like his work situation more. Feelings related to work satisfaction and dissatisfaction depict the worker's interpretation on his current and past working experiences rather than on future expectation. This is in accordance with what (Robbins, 2003) said that the term job satisfaction refers to an individual's general attitude toward his or her job. A Person with a high levelof job satisfaction holds positive attitudes toward the job, while a person who is dissatisfied with his or her job holds negative attitudes towards the job.

The relation between job satisfaction and OCB can be found in (Richard L. Hughes, Robert C. Ginnet and Gordon J. Cuurphy, 2009), which said "research has also shown that people who are more satisfied with their jobs are more likely to engage in organization citizenship behavior

\section{LITERATURE REVIEW}

\section{Organization Citizenship Behavior (OCB)}

Organization Citizenship Behavior (OCB) is an employee's behavior intended to help coworkers or the organization. (Paul E. Spector, 1997) defined this as "organizational citizenship behavioror OCB is behavior by an employee intended to help coworkers or the organization. Next, Schermerhorn stated that, "organizational citizenship behavior is a willingness to go beyond the call of duty or go to the extra mile in one's work". Then, (Colin P. Silverthone, 2005), stated that "Organizational citizenship behavior represent individual behavior that is discretionary, not directly or explicitly recognized by the formal reward system, and in the aggregate promotes the efficient and effective functioning of theorganization". Furthermore, (Paul M. Muchinskty, 2006), believed that an employee or "a good soldier" must have some dimensions of OCB, five dimensions are most frequently proposed by researchers: Altruism (also called helping behavior) reflects willfully helping specific people with an organizationally relevant task or problem; Conscientiousness refers to being punctual, having attendance better than the group norm, andjudiciously following company rules, regulations, and procedures; Sportmanship refers to avoiding complaints, petty grievances gossiping, falsely magnifying problems; Courtesyis being mindful and respectful of other people's rights; Civic virtue is responsible participation in the political life of the organization. Civic virtue reflects keeping abreast of not only current organizational issues but also more mundane issues, such as attending meetings, attending to in-house communications, and speaking up to issues. It has been suggested that civic virtue is the most admirable manifestation of organizational citizenship behavior because it often entails some sacrifice of individual productive efficiency.

\section{Self Efficacy}

(Bandura, 2008), who was the first to introduce the concept of self efficacy, stated that"efficacy beliefs effect self-motivation and action through their impact on goals and aspiration. It is partly on the basis of efficacy beliefs that people choose what goals challenges to undertake, how much effort to invest in the endeavor, and how long to persevere in the past of difficulties". (Fred Lutans, 2011), "self-efficacy refers to an individual's convection (or confidence) about his or her abilities to mobilize the motivation, cognitive resources, and courses of action needed to successfully execute a specipic task within a given contect. Self efficacy is the skill to achieve result or output, ability to recognize effective actions. Self 
efficacy is related to personal belief regarding his or her competence and capbility. Competence shows one's confidence towards his or her ability or capability in performing his tasks well. Competence is often defined as the concept of self efficacy; employees with strong competence have better belief that they have the capability in performing special tasks needed to achieve success in his work. (Stephen Robbins and Timothy A. Judge, 2015) said, "self efficacy (also known as social cognitive theory or social learning theory) refers to an individual's belief that he or she capable of performing a task". Meanwhile, (James L. Gibson, 2012), said "self efficacy is a belief that we can perform adequately in a particular situation".

\section{Job Satisfaction}

In an organization, job satisfaction is commonly used as the measurement of the organization's maturity level. One aspect that may disrupt the condition in an organization is low rating of job satisfaction. On the other hand, high rating of job satisfaction shows that the organization has been well-managed. The concept of job satisfaction according to (Mullins, 2010) is complicated, "Job satisfaction is a complex and multifaceted concept, which can mean different things to different people." (Newstrom, 2011) believed that "Job satisfaction is a set of favorable or unfavorable feelings and emotions with which employees view their work. Job satisfaction is a affective attitudes a feeling of relative like or dislike toward something (for example, a satisfied employee may comment that "I enjoy having the variety of tasks to do")." (Schermerhorn, 2010) defined job satisfaction as, "Job satisfaction is the degree to which an individual feels positive or negative about various aspcets of work." (Jason Colquitt Jeffery A. Lepine, Michael J. Wesson, 2015), stated that "Job satisfaction is defined as a pleasurable emotional state resulting from the appraisal of one's job or job experiences."

\section{METHODOLOGY}

This research uses quantitative approach method with survey. (Gay, Mills, and Airasian, 2011) describes a survey research as "Survey research involves collecting data to test hypotheses or to answer quetions about people's opinions on some topic or issue. A Survey is an instrument to collect data that describe one or more characteristics of a spesific population". The survey method involved data collecting to test hypothesists or to answer questions on several topics or problems. A survey is an instrument to collect data that explain one or more characteristics of certain populations. The target population in thes research is all public senior primary school teachers in Sukoharjo Regency. Slovin formula is used to determine the number of the sample used as the object of the research.

The inter-variable effect in this research is analyzed using path analysis. This technique of analysis is believed to have the usability to test the inter-variable effect based on the theoritical formula rather than to decrease the causal effect. The consequence of using this technique is the obligation to use causal thinking method which is required in path analysis.

\section{FINDINGS}

\section{Positive Direct Effect of Self Efficacy Towards OCB}

From the calculation of path coefficion, a positive direct effect of self efficacy towards OCB was found. $\mathrm{OCBP}_{\mathrm{y} 1}$ was 0,239 . The $t_{\text {count }}=3,27$, while the $t_{\text {table }}$ was in the level of significance of $\propto(0,05)=1,97$. Since $t_{\text {count }}>t_{\text {table }}$, then $H_{0}$ was rejected and $H_{1}$ was accepted. Therefore, it can be concluded that self efficacy has positive direct effect towards OCB.

\section{The Effect of Job Satisfaction Towards OCB}

From the calculation of path coefficion, a positive direct effect of job satisfaction towards OCB was found. $\mathrm{OCBP}_{\mathrm{y} 2}$ was 0,235 . The $t_{\text {count }}=3,22$ while the $t_{\text {table }}$ was in the level of significance of $\propto(0,05)=1,97$. Since $t_{\text {count }}>t_{\text {table }}$, then $H_{0}$ was rejected and $H_{1}$ was accepted. Therefore, it can be concluded that job satisfaction has positive direct effect towards OCB.

\section{Positive Direct Effect of Self Efficacy Toward Job Satisfaction}

From the calculation of path coefficion, a positive direct effect of self efficacy towards job satisfaction was found. $P_{21}$ was 0,21 . The $t_{\text {count }}=2,90$, while the $t_{\text {table }}$ was in the level of significance of $\propto(0,05)=1,97$. Since $t_{\text {count }}>t_{\text {table }}$, then $\mathrm{H}_{0}$ was rejected and $\mathrm{H}_{1}$ was accepted. Therefore, it can be concluded that self efficacy has positive direct effect towards job satisfaction.. 


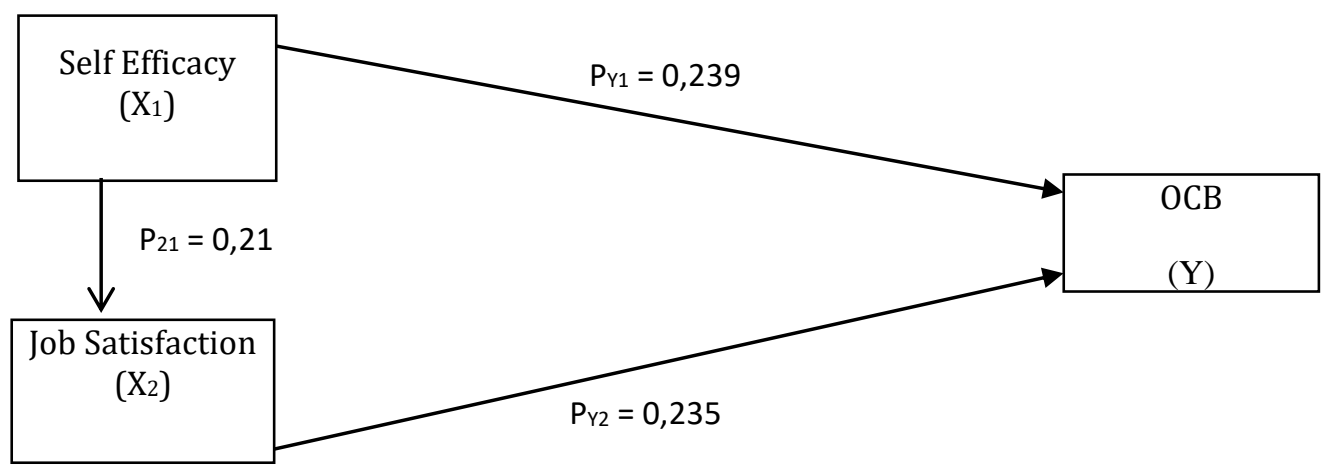

Picture 1. Structural Mode of Inter-variable Effect

\section{DISCUSSION}

The result taken from model analysis was used as the base in answering hypothesis and drqaw conclusion in this research. The explanation of the answer to the hypothesis is described as follows:

\section{Positive Direct Effect of Self Efficacy (X1) Towards OCB (Y)}

The first hypothesis anlaysis resulted a new finding that self efficacy has positive direct effect towards OCB. Based on the finding, it can be concluded that OCB was directly affected positively by self efficacy. The increase on self efficacy will result in increased OBC.

Individuals with positive behavior will feel satisfied with their job more. In addition, those who have positive behavior tend to be more helpful with their coworkers and often increase the OCB. Similar opinion was proposed by (Jex, 2002) in relation with some dimensions that can increase OCB "Why do employees engage in OCB? There are actually three different explanations. According to the first, the primary determinant is positive affect, tipically in the form of job satisfaction".

Regarding this matter, (Jex, 2002) explained how to increase employees' OCB, that can be exposed in thre different explanations. The first and the quite important is the positive bahavior, the typical form of job satisfaction. In a bit different definition, (Jex, 2002) also stated that "research has showen that employees engage in OCB primarily because of positive affect and perceptions of the level of fairness with which they are treated by the organization." Researches show that the increase in OCB is basically affected by positive behavior and perspective towards justice mechanism implemented by the organization. The statement above is in accordance with the findings in this research, that self efficacy has direct positive effect towards OCB.

\section{Positive Direct Effect of Job Satisfaction (X2) Towards OCB (Y)}

The third hypothetis analysis resulted a finding that job satisfaction has positive direct effect towards OCB. Based on the finding, it can be concluded that OCB was directly affected positively by job satisfaction. The increase on job satisfaction will result in increased OBC. This is in accordance with a statement from (James Campbell Quick, Debra L. Nelson, 2013) saying that "job satisfaction is related to many other important personal and organizational outcomes, such as OCB, which is voluntary behavior above and beyond the call of duty. Satisfied employees are more likely to make positive comments about the company, refrain from complaining when things at work do not go well, and help their coworkers."

Job satisfaction is related to many interests, both personal and organizational, like OCB which is a voluntary behavior towards one's job and beyond his tasks. Satisfied employees will be more likely to produce positive comments about their company, to restrain from complaining when things do not go well and to help their coworkers.

\section{Positive Direct Effect of Self Efficacy $\left(X_{1}\right)$ Towards Job Satisfaction $\left(X_{2}\right)$}

The fifth hypothetis analysis resulted a finding that self efficacy has positive direct effect towards job satisfaction. Based on the finding, it can be concluded that job satisfaction was directly affected positively by self efficacy. The increase on self efficafy will result in increased job satisfaction.

This is in accordance with a statement from (Jong Ho Choi, 2008) in his dissertation entitled "Opening The Black Box: The Medianting Effect of Employee Atitudes In The relationship Between High performance Work Systems and Form Performance." It is said that Judge and Bauer argued that self efficacy should affect job satisfaction insofar as self efficacy is associated with practical success on the job. 
Because individuals with high self efficacy deal more effectively with difficulties and persist in the face of failure.

Then, (Q. Ashton Acton, 2012) stated that female teacher had greater workload stress, greater classroom stress from student behaviors and lower classroom management self efficacy. Teachers with greater workload stress had greater classroom stress had lower self efficacy and lower job satisfaction. The researchers concluded: ... Lastly, teacher with greater classroom management self efficacy or greater instructional strategis self efficacy had greater job satisfaction. Female teachers have more workload stress than their male counterparts. The stress comes from the student behaviors and low classroom management. The greater workload stress result in low self efficacy and job satisfaction. Researchers concluded that teachers with high self efficacy have greater job satisfaction.

\section{CONCLUSION}

Based on the result of the research and the discussion, it can be concluded that (1) self efficacy has positive direct effect towards OCB. This means that the increase in self efficacy resulted in greater OCB of teachers in public primary school in Sukoharjo Regency; (2) jobs satisfaction has positive direct effect towards OCB. This means that the increase in job satisfaction resulted in greater OCB of teachers in public primary school in Sukoharjo Regency; (3) self efficacy has positive direct effect towards job satisfaction. This means that the increase in self efficacy resulted in greater job satisfaction of teachers in public primary school in Sukoharjo Regency.

\section{REFERENCES}

\section{Books}

Bandura,. (2008). Cultivate self-efficacy for Personal and Organization Efecyieness. Handbook of Principle of Organization Behavior. New York: Willey

ColinP.Silverthone. (2005). OrganizationalPsychologyin Cross-cultural Perspective. NewYork:NewYork UniversityPress.

Consuelo G. Sevillia at. al., (1993). Pengantar Metode Penelitian. Jakarta: Penerbit Universitas Indonesia.

Fred Luthans. (2011). Organizational Behavior: An Evidence-Based Approach. USA: McGraw-Hill.

Jason A. Colquitt, Jeffrey A, Lepine and Michael J Wesson. (2015). Organization Behavior Improving Performance and Commitment in the Workplace, 4 edition. New York: Mc Graw Hill.

James Campbell, Quick, Debra l Nelson. (2013). Principles of Organizational Behavior Realities and Challenges, 8 Edition. China: South-Western Cengange Learning.

James Campbell Quick, Debra L. Nelson. (2009). Principle of Organization Behavior, Realities and Challenges. South-Western: Engage in Learning.

James L. Gibson, et. al.,. (2012). Organization: Behavior, Structure, Process. New York: McGraw Hill.

James L.Gibson, James H.Donnelly, JR, John M. Ivancecivh, Robert Konopakse. (2012). Organizational Behavior Structure Process, 14 edition. New York: McGraw-Hill.

Jong Ho Choi. (2008). Opening The Black Box: The Medianting Effect of Employee Atitudes In The Relationship Between High Performance Work Systems and Form Performance. Emerald Insight. Medison: ProQuest LIC.

John R. Schermerhorn, et. al., (2010). Organizational Behavior. USA: John Willey and Sons.

John M. Ivancevich, Robert Konopaske, Michael T. Matteson. (2011). Organizational Behavior and Management. New York: McGraw-Hill Companies, Inc.

John W. Newstrom. (2011). Human Behavior at Work. Thirteenth Edition. New York: McGraw-Hill Companies Inc.

Jhon W. Newstorm and Keith Davis. (2002). Organizational Citizenship Behavior, Human Behavior at Work, $11^{\text {th }}$ Edition. Boston: McGraw-Hill.

Laurie J. Mullins. (2010). Management and Organizational Behaviour 9 Edition. New Jersey: Pearson Prentice-Hall.

Paul M. Muchinskty. (2006). Psychology Applied to Work, 8 Edition. United States of America: Thomson Wardworth.

PaulE.Spector. (1997). Job Satisfaction: Application, Assessment, Causes,and C onsequences. London: SagePublications,Inc.

Richard L. Hugnes, Robert C. Ginnett and Gordon J. Curphy. (2009). Leadership Enhancing The Lesson Of Experience Sixth Edition. Singapura: McGraw-Hill. 
Ricky W. Grifin, Gregory Moorhead. (2014). Organizational Behavior Managing People and Organizational, $11^{\text {th }}$ Edition. USA: South Western Cengange Learning.

Robert P. Vecchio. (2006). Organizational Behavior Core Concept, $6^{\text {th }}$ Edition. USA: Thomson South Western.

Sunaryo. (2004). Psikologi untuk Keperawatan. Jakarta: EGC.

Stephen Robbins. (2003). Essentials of Organizational Behavior, $7^{\text {th }}$ Edition. New Jersey: Pearson Education, Inc.

Steve M Jex. (2002). A Scientist-Practitioner Approach Organizational Psychology. New York: Jhon Wiley \& Son.

Steven L.McShane, Mary Ann Von Glinov. (2010). Organizational Behaviour Emerging Realities for The Workplace Revolution, 5 Edition. New York: McGraw-Hill Comapanies, Inc.

Q. Ashton Acton. (2012). Issues In Perception, Cognition, Development, And Personality. Atlanta: Scholarly Editions.

\section{Journals}

Debora Purba \& Liche Seniati. (2004). Pengaruh Kepribadian dan Komitmen Organisasi terhadap OCB. Jurnal Ilmiah Sosial Humaniora, Vol. 8 No. 3, 2004.

I Made Darsana. (2014). The Influence of Personality on Employee Performance through Organization Citizenship Behavior. The International Jurnal of Management, Vol 3 Issue 4, Oktober 2014.

Imran Ramdani. (2017). Pengaruh Kepribadian, Komitmen Organisasi dan Kepuasan Kerja terhadap OCB pada Karyawan PT. Patra SK. Jurnal Administrasi Bisnis LP3I Jakarta, Vol. 7 No. 2, 2017.

Indah Puji Lestari, Diana Sulianti, dan Gusti Wulandari. (2015). Pengaruh Self Efficacy dan Organizational Behavior (OCB) terhadap Kinerja Pegawai dengan Kepuasan Kerja sebagai Variabel Intervening. Jurnal Ilmiah Manajemen UNEJ, Vol. 6 No. 1, 2015.

Ni Made Sintya Dewi \& I Gede A. Sudibya. (2016). Pengaruh Efikasi Diri terhadap OCB dengan Kepuasan Kerja sebagai Variabel Mediasi. E-Jurnal Manajemen Unud, Vol. 5 No. 11, 2016.

Syamsuddin, La Ringgasa, \& Badarwan. (2017). The Effect of Self-efficacy on Organizational Citizenship Behavior (OCB) Employees of Institute Agama Islam Negeri Kendari. Jurnal Ilmiah IAIN Kendari, Vol. 3 No. 2, 2017. 